Balkan Araştırma Enstitüsü Dergisi / Journal of Balkan Research Institute Cilt/Volume 8, Say1/Number 2, Aralık/December 2019, ss. 367-384.

DOI: 10.30903/Balkan.657755

ARAȘTIRMA MAKALESİ - RESEARCH ARTICLE

\title{
GÖRİCE SANCAĞINDA DEPREMLER (1893-1912)
}

\section{Özer ÖZBOZDAĞLI*}

\begin{abstract}
ÖZ
Manastır vilayeti depremsellik açısından Osmanlı Makedonyası'nın en riskli ve Balkan Yarımadasının en aktif sismik bölgelerinden biridir. Manastır vilayetinde meydana gelen depremlerin Struga-Ohri-Görice hattında yoğunlaştı̆̆ görülmektedir. İncelenen tarihler arasında Manastır-Ohri-Görice hattında farklı şiddetlerde sık depremlerin yaşandığı tespit edilmiştir. Bu çalışmada Manastır vilayetinde StrugaOhri-Görice hattında 1893-1912 yılları arasında meydana gelen depremler arşiv belgelerinden elde edilen verilerle değerlendirilecek ve kayıt altına alınacaktır. Bununla birlikte depremlerin en önemli konu başlıklarından olan afet yönetimi ve depremin toplum üzerindeki etkilerinin azaltılması konusu, Makedonya meselesinin uluslararası bir sorun haline geldiği bir dönemde Osmanlı Devleti için öncelikli sorunlardan biriydi. Osmanlı Devleti'nin depremin toplum üzerindeki etkilerini azaltmak için afet yönetimi konusunda yaptığı çalışmalara değinilecektir.
\end{abstract}

Anahtar Kelimeler: Görice, Deprem, Makedonya, Manastır Vilayeti, Ohri

\section{EARTHQUAKES IN THE SANJAK OF KORÇA 1893-1912}

\begin{abstract}
Monastery province is one of the riskiest of Ottoman Macedonia and Balkan Peninsula in terms of seismicity. It is observed that earthquakes happening in the Monastery province are concentrated on the Struga-Ohri-Korça line. It is detected that frequent earthquakes with various magnitudes happened on the Monastery-OhriKorça line between examined dates. In this study, earthquakes happened on the Struga-Ohrid-Korça line in the Monastery province between the years of 1893-1912 will be evaluated and recorded with data obtained from archival documents. On the other hand, reducing the effects of disaster management and earthquake on the
\end{abstract}

* Dr. Öğretim Üyesi, Hatay Mustafa Kemal Üniversitesi, Fen-Edebiyat Fakültesi Tarih Bölümü, Antakya, ORCID: orcid.org/ 0000-0003-3486-7270, E-mektup: oozbozdagli@gmail.com 


\section{ÖZER ÖZBOZDAĞLI}

society, which is considered one of the most crucial topic titles of earthquakes was one of the priorities for Ottoman Empire at a time when the Macedonia issue became an international problem. Disaster management efforts of the Ottoman Empire for reducing the effects of earthquake on the society will be discussed.

Keywords: Korça, Earthquake, Macedonia, Monastery Province, Ohrid

\section{Giriş}

Deprem doğrudan doğruya kaynağını yer kabuğu veya yerin derinliklerinden alan bir doğal afettir. Doğal etkenlere bağlı olarak yerkabuğunda görülen ve çoğunlukla yeryüzünde önemli değişikliklere neden olabilen kısa süreli salınım ve titreşim hareketlerine deprem denmektedir. Ani olarak ortaya çıkan ve önlenmesi mümkün olmayan bu doğa olayı, büyük can ve mal kayıplarına neden olduğu gibi birey üzerinde ve toplumda sosyopsikolojik yönden ciddi olumsuzluklar da yaratmaktadır. ${ }^{1} \mathrm{Bu}$ sebeple deprem doğal afetlerin en tehlikeli ve yıkıcı olanıdır. Depremler, Osmanlı coğrafyasında en sık yaşanan doğal afetlerin başında gelmektedir. Osmanlı coğrafyasının bir parçası olan Balkan coğrafyası da deprem riski yüksek alanlardan biri olup Avrupa'nın sismik olarak en aktif bölgelerinden biridir. Makedonya bölgesi ise Balkan yarımadasının en yüksek sismik tehlike ve risk alanlarından biridir. Makedonya'nın sismikliği öncelikle tektonik blokların dikey hareketi ile ilişkili yıkıcı süreçlerle ilgilidir. Balkan yarımadasının bir parçası olarak Makedonya geçtiğimiz yüzyıllarda meydana gelen çok sayıda depremden etkilendi. Üsküp-Vardar ve Manastır-Ohri-Görice bölgeleri depremlerin en sık yaşandığı bölgelerdir.

Geçmiş örneklerin incelenmesi deprem hareketlerinin anlaşılabilmesi ve öngörüde bulunulabilmesi için önemlidir. Tarihi kayıtlar incelendiğinde Makedonya bölgesinin şiddetli depremlere maruz kaldığı görülmektedir. Yer kabuğunun hareketlerini inceleyen deprembilimciler Manastır, Debre ve Ohri'nin olası deprem riskleri taşıyan yerler olduğunu belirtmektedirler. Manastır vilayetinde meydana gelen depremlerin Struga-Ohri-Görice hattında yoğunlaştığı görülmektedir. Bu hat günümüzde yapılan sismolojik araştırmalarda Batı Makedonya sismik bölgesinde yer almaktadır ve Balkan

1 Cemalettin Şahin-Şengün Sipahioğlu, Doğal Afetler ve Türkiye, Gündüz Eğitim ve Yayıncılık, Ankara 2007, s. 26. 


\section{GÖRICE SANCAĞINDA DEPREMLER (1893-1912)}

yarımadasının en aktif sismik bölgelerinden biridir. $^{2}$ Ohri-Görice(Korça) bölgesi son birkaç yüzyıl içinde sık sık depremlerin yaşandığı ArnavutlukMakedonya Koridoru'ndaki en yüksek sismik tehlikeye sahip bölgelerden biri olarak kabul edilmektedir. ${ }^{3}$ Tarihsel dönemlerde bu bölgede büyük depremler meydana gelmiştir. Örneğin; M.S. 518'de meydana gelen depremle Ohri antik kenti ve göl çevresindeki diğer yerleşim yerleri tamamen yıkılmıştır. ${ }^{4}$

Bu çalışmada Manastır vilayetine bağlı Görice sancağında 1893-1912 yılları arasında arşiv belgelerinden tespit edebildiğimiz depremler ve sonuçları üzerinde durulacaktır. İncelenen tarih aralığında Osmanlı arşiv belgelerine ve güncel araştırmalara yansıyan bilgiler karşılaştırmalı olarak ele alınacaktır. Osmanlı belgelerinde deprem için "hareket-i arz", "zelzele" "tezelzülat", "tezelzül" gibi ifadeler kullanılmaktadır. Depremin şiddeti ve süresi; "şiddetli”, "çok şiddetli”, "pek şiddetli”, "hafif", "sürekli", "süreksiz" gibi ifadelerle tasvir edilmektedir. Bununla birlikte Osmanlı devletinde depremi değerlendirecek teknik eleman ve aletsel alt yapının olmaması Osmanlı belgelerinin de sınırlarını çizmektedir. Bölgenin tektonik koşulları, depremin doğa üzerindeki etkileri, yerleşim yerinin özellikleri, yapıların hassaslığı, yapı malzemesi, binaların durumu, kırsal bölgelerdeki yapılar, şehirlerin yeniden inşası, inşa edilen yapıların özelliği, onarımı yapılan binalarda ne gibi güçlendirme faaliyetleri yapıldığı, daha sonra meydana gelebilecek depremlerle ilgili risk analizlerinin yapılıp yapılmadığıyla ilgili bilgilerin Osmanlı arşiv belgelerine sınırlı ya da hiç yansımaması belgelerle yapılacak bir deprem çalışmasının en önemli zorluğu olduğunu belirtmek gerekir. 1900 yllı öncesinde meydana gelen depremler, bilimsel olarak aletsel ölçümler başlamadan önce meydana geldiği için sismik verileri yoktur. Bu sebeple deprem ile ilgi bilgiler Osmanlı arşiv belgelerinden ortaya çıkan verilerle kayıt altına alınacaktır.

\footnotetext{
${ }^{2}$ Batı Makedonya sismik bölgesi: Tetova-Gostivar, Debar, Kırçova, Kruşevo, Debarca-Plaken dağı, Pestani-Ohri-Struga, Prespa, Bitola, Bitola-Lerin, Ohri gölünün güneyi. Diğer iki bölge Vardar ve Doğu Makedonya sismik bölgeleridir. Bu üç bölgenin ayrı birer sismik bölge olarak kabul edilmelerinin nedeni sismik faaliyette farkl1lı göstermeleridir. Bkz. "Seismicity of Republic of Macedonia: Tectonics and observed seismicity", http://seismobsko.pmf.ukim.edu.mk/index.php/mk/seismicity/seismicity-of-republic-ofmacedonia/observed/ seismicity/54-tectonics-and-observed-seismicity, (28.7.2019).

${ }^{3}$ Klaus R. Reicherter, Tomas Manuel Fernandez-Steeger, "Active Tectonics in the Ohrid Basin (Macedonia/Albania)", EGU General Assembly, April 2009, s. 1-2.

${ }^{4}$ Mentor Sulollari, "Natural Hazards in the Albanian Area of Lake Ohrid", Annals of Valahia University of Targoviste. Geographical Series, 2016, s. 88; Zoran Milutinovic-Dragana Anastasovska ve diğerleri, "Seismic Hazard and Review of Seismic Activity of the Ohrid Epicentral Area in the Period June-July 2017”, Geographical Reviews, s. 42.
} 


\section{ÖZER ÖZBOZDAĞLI}

Manastır vilayeti 1878 tarihinden sonra Makedonya 1slahatının içerisinde yer aldı. Makedonya 1877-1878 Osmanlı-Rus Savaşı'ndan sonra Ayastefanos Antlaşması'nın yerine imzalanan 13 Temmuz 1878 Berlin Antlaşması'yla reformlar yapılması koşuluyla Osmanlı idaresine bırakıldı. Osmanlı Makedonyası Selanik, Manastır ve Kosova vilayetlerinin bazı kesimlerinden (özellikle Üsküp) oluşmaktaydı. Bu tarihten sonra Makedonya sorunu Balkan ve Avrupalı devletlerin müdahaleleriyle kronikleşen uluslararası bir sorun olarak Osmanlı Devleti'nin gündemine oturdu. Osmanlı Devleti Makedonya'da komitacilarla mücadele ederken, bir taraftan da Avrupalı devletlerin reform taleplerini karşılamak zorunda kalmıştır.

\section{1893 Depremi}

Manastır vilayetine bağlı Görice sancağında 19 Haziran 1309 (2 Temmuz 1893) tarihinde "şiddetli" ve birbirini takiben depremler meydana gelmiştir. ${ }^{5} 1893$ yılında Görice sancak olarak Manastır vilayetine bağlanmıştır. Görice sancağı; Görice, Kesriye, Kolonya ve İstarova kazalarından oluşmaktaydı. 1893-1894 yıllarında kazaya tabi nahiye sayısı altı olmuştur. Sancak dâhilinde 385 köy vardır. ${ }^{6}$

Deprem ile ilgili Görice mutasarrıflığından gelen ilk bilgilerde; hükümet konağı, hapishane ve hanelerin önemli bir kısmının zedelendiği, ahalinin hanelerinden dışarıya çıktığı, mahkûmların da hapishanenin dışına çıkarıldığı, ölü ve yaralı olmadığı bildirilmiştir. Sancak merkezindeki telgrafhane tahliye olunarak telgrafhane bahçesinde işletilmeye başlanmıştır. ${ }^{7}$ Zabıtan ahalinin ve mahkûmların güvenliğini sağlamaya çalıştığ için Hurpeşte'deki nizamiye birliğinden bir bölük asker talep edilmiştir. Ancak askeri makamlar asker gönderilemeyeceğini belirtmişlerdir. ${ }^{8}$ Deprem Görice kırsalında da hasara neden olmuştur.

Görice'ye bir saat mesafede Zenişçine köyünde 20'ye yakın Hristiyan'ın hanesinin yıkıldığ1 belirtilmiştir. Görice mutasarrıflığı depremzedeler için ilk etapta 200 çadır talep etmiştir. ${ }^{9}$ Dışarıda kalıp baraka

${ }^{5}$ BOA, DH. MKT, 79/15, 23 Haziran 1309 (5 Temmuz 1893).

${ }^{6}$ Mucize Ünlü, Manastır Vilayeti'nin İdari ve Sosyal Yapısı (1873-1912), Ondokuz Mayıs Üniversitesi Sosyal Bilimler Enstitüsü, Yayınlanmamış Yüksek Lisans Tezi, Danışman: Yrd. Doç. Dr. M. Emin Yolalıc1, Samsun 1996, s. 50.

${ }^{7}$ BOA, Y.A. HUS, 271/42, 21 Haziran 1309 (3 Temmuz 1893).

${ }^{8}$ BOA, Y.A. HUS, 271/42, 21 Haziran 1309 (3 Temmuz 1893).

${ }^{9}$ BOA, DH. MKT, 79/15, 23 Haziran 1309 (5 Temmuz 1893). 


\section{GÖRİCE SANCAĞINDA DEPREMLER (1893-1912)}

yaptıramayanlara ve devlet personeli için padişahın talimatıyla askeri makamlardan çadır gönderilmiştir. ${ }^{10}$ Açıkta kalan ahali için Manastır'dan 97, Ohri'den 107 çadır Görice'ye nakledilmiştir. ${ }^{11}$ Çadırların değeri 117.200 kuruş olarak tespit edilmiştir. Depremzedelere gönderilen çadırların kullanılamaz hale gelmesi askeri makamlar için ciddi bir sorundu. Bu sebeple askeri makamlar çadırların parasının ödenmesi konusunda 1srarcı olmuşlardır. ${ }^{12}$ Çadırların değeri olan 117.200 kuruşun 1894 yılı Manastır vilayeti emval-i umumiyesinden doğrudan askeri makamlara gönderilmesi talimatı verilmiştir. ${ }^{13} 204$ çadırın hükümetin işine yaramayacağ 1 ve askeriyeye iadesi uygun olmayacağ durumunda kullanılmak üzere zabita alay deposuna konulması kararlaştırılmıştır. ${ }^{14}$

Osmanlı Hükümeti; askeri makamlar tarafindan depremzedelere dağıtılan bu çadırlar bir daha kullanılmayacak duruma geldikleri için yeni masraflara yol açtığı ve askeri makamlara ait olan bu çadırların dağıtılmasının yasak olduğu belirtilerek olağanüstü durumlarda çadır talep edilmeyip barakalar inşa edilmesini kararlaştırmıştır. Bu karar üzerine Manastır vilayetine Görice'deki depremzedeler için baraka inşa edilmesi talimatı verilmiştir. ${ }^{15}$ Bununla birlikte hava şartlarının kötü olması nedeniyle açıkta kalan halk ve devlet personeli için 20 baraka yapılmıştır. ${ }^{16}$ Barakaların yapılmasından sonra kötüleşen hava koşulları nedeniyle ahalinin çadırlarda barınamadığı belirtilerek barakalara yerleştirilmesi ve çadırların toplatılmasına karar verilmiştir. ${ }^{17}$

Deprem sırasında afet yönetiminin en önemli konu başlıkları iaşe ve barınma ihtiyaçlarının karşılanması konusuydu. Osmanlı devleti barınma ihtiyaçlarının karşılanması konusuna önem vermekle birlikte özellikle fakir halkın barınma sorunlarının çözülmesi ve hanelerinin onarımı konusunda

\footnotetext{
${ }^{10}$ BOA, DH. MKT, 102/33, 25 Ağustos 1893 (7 Eylül 1893); BOA, BEO, 276/20686, 2 Eylül 1309 (15 Eylül 1893).

${ }^{11}$ BOA, DH. MKT, 132/32, 2 Teşrin-i sani 1309, (15 Kasım 1893).

12 BOA, I. DH, 1307/16, 25 Ağustos 1309, (7 Eylül 1893).

${ }^{13}$ BOA, DH. MKT, 132/32, 15 Teşrin-i sani 1310 (28 Kasım 1894); BOA, BEO, 122/31639, 9 Haziran 1310 (22 Haziran 1894).

${ }^{14}$ BOA, DH. MKT, 102/33, 27 Kanun-i sani 1309 (8 Şubat 1894).

${ }^{15}$ BOA, DH. MKT, 102/33, 13 Eylül 1309 (26 Eylül 1893).

${ }^{16}$ Sevk edilen çadırların nakliyesi için toplam 524 kuruş, 20 adet barakanın inşası için toplam 2882 kuruş olmak üzere toplam 3919 kuruş masraf yapılmıştır. BOA, DH. MKT, 132/32, 2 Teşrin-i sani 1309, (15 Kasım 1893).

${ }^{17}$ BOA, DH. MKT, 102/33 27 Teşrin-i evvel 1309 (7 Kasım 1893).
} 


\section{ÖZER ÖZBOZDAĞLI}

hassast1. Manastır valiliği, Dâhiliye Nezareti'ne gönderdiği telgrafta; Görice'de meydana gelen şiddetli depremden dolayı harap olan fakirlere ait hanelerin kış gelemeden tamiri için vilayet genelinde iane toplanmasının zaruri bir hal aldığını, ancak zirai açıdan bereketsiz bir yıl olması nedeniyle ihtiyacı karşılayacak derecede iane toplanamayacağını, vilayetçe 25.000 kuruş civarında toplanan iane dışında bir yardımın temin edilemeyeceğini belirtmiştir. Valilik, kış mevsiminin yaklaşmasından dolayı iane konusunda yapılacak teşebbüsün hemen yapılmasın ${ }^{18}$ ve diğer vilayetlerden ve Dersaadet'ten iane toplanmasını talep etmiştir. ${ }^{19}$ Bunun üzerine Osmanlı Hükümeti, vilayetçe toplanan ianeye ek olarak 25.000 kuruşun 1894 yılı padişahın özel hazinesinden karşılanması için 15 Eylül 1309 (28 Eylül 1893) irade-i seniyye yayınlad.$^{20} \mathrm{Bu}$ bağlamda Manastır vilayetine 25.000 kuruşun vilayetin 1893 yılı emval-i umumiyesinden karşılanması talimatı verilir. Vilayet bütçesinden karşılanan meblağın daha sonra padişahın özel hazinesinden vilayet bütçesine aktarılacağı belirtilmiştir. ${ }^{21}$

Görice'de arţ̧ı sarsıntılar 1893,1894 yıllarında devam etmiştir. 12 Ağustos 1309 (25 Ağustos 1893) tarihinde saat üçten sonra üç defa şiddetli ve bir defa hafif deprem meydana geldiği ve bunun sonucunda bir hanenin duvarlarının yıkıldığı bildirilmiştir. ${ }^{22}$ Dönemin kaynakları ve deprem bilimciler Görice bölgesinden 600 artçı şokun bildirildiğini belirtmektedir. ${ }^{23}$ Artçı şoklar 1894 yılında da devam etmiştir. Manastır Maarif Müdürlüğü 1

${ }^{18}$ BOA, I.DH, 1307/42, 29 Ağustos 1309 (11 Eylül 1893).

${ }^{19}$ BOA, DH. MKT, 131/3, 31 Ağustos 1309 (13 Eylül 1893).

${ }^{20}$ BOA, I.DH, 1307/42, 1 Eylül 1309 (14 Eylül 1893); BOA, BEO, 283/21217(10 Eylül 1893).

${ }^{21}$ BOA, DH. MKT, 79/15, 19 Eylül 1309 (2 Ekim 1893).

${ }^{22}$ BOA, Y.A. HUS, 279/99, 12 Ağustos 1309 (25 Ağustos 1893).

${ }_{23}$ Nicholas Ambraseys, Earthquakes in the Mediterranean and Middle East, Cambridge University Press, UK 2009, s. 770; Manastır vilayetinde 22 Mart 1320 (4 Nisan 1904) Pazartesi günü birincisi hafif, ikincisi şiddetli olmak üzere iki deprem meydana gelmiştir. Pirlepe kazasında 22 Mart'ta (4 Nisan) 2 kez şiddetli, 2 hafif olmak üzere toplam 4 sarsıntı meydana gelmiştir. Pirlepe kazasında depremde hanelerde kısmi çatlaklar meydana geldiği, halkın evlerinde kaldığı, Rum kilisesi ve Bulgar mektebinin duvarlarında çatlaklar oluştuğu ancak olağan faaliyetlerine devam ettiği bildirilmiştir. Depremde kısmi hasarlı mesken sayısının 100 olduğu ve bir kişinin hayatını kaybettiği belirtilmiştir. Pirlepe'de 8 Nisan'da saat 7.18'de ve 10 Nisan'da 3.35'te iki kez şiddetli sarsıntı meydana gelmiştir. Debre sancağında ise 5 Nisan'da 5 defa şiddetli deprem meydana gelmiş̧ir. Manastır'da 8 Nisan'da 7.30'da sarsıntı meydana gelmiştir. 4 Nisan'da Serfice sancağına bağlı Kayalar kazasında bir, Ohri kazasında ve Görice sancağında ikişer defa şiddetli deprem meydana gelmiştir. Bkz. BOA, BEO, 2307/173008, 22 Mart 1320; Sabah, Nr: 5200, 26 Muharrem 1322 (Hicri), 31 Mart 1320 (Rumi), 13 Nisan 1904 (Miladi), s. 3; Sabah, Nr: 5200, 31 Mart 1320 (Rumi), 13 Nisan 1904 (Miladi), s. 3; BOA, DH. MKT, 838/47, 25 Mart 1320 (7 Nisan 1904); BOA, DH. MKT, 838/47, 25 Mart 1320 (7 Nisan 1904); BOA, DH. MKT, 838/47, 25 Mart 1320 (7 Nisan 1904). 


\section{GÖRICE SANCAĞINDA DEPREMLER (1893-1912)}

Aralık 1894 tarihinde Maarif Nezaretine gönderdiği bir yazısında birkaç gündür artan şiddette depremlerin yaşandığını belirtmiştir. ${ }^{24}$

Osmanlı arşiv belgelerinden ve son yapılan araştırmalardan Manastır vilayetinin İlbasan, Florina, Görice, Debre-i Bala ve Debre-i Zir bölgelerinde 1904 yılına kadar muhtelif tarihlerde depremler meydana geldiği anlaşılmaktadır. $\mathrm{Bu}$ depremlerin listesi eklerde verilmiştir. Bununla birlikte 22 Mart 1904 (4 Nisan 1904) tarihinde saat 10.25'te Selanik, Manastır ve Kosova vilayetlerinde deprem meydana geldi. ${ }^{25} 1904$ depremi Kosova ve Selanik vilayetlerinde ciddi hasara ve can kaybına yol açmıştır. Deprem, özellikle Üsküp kırsalında ciddi tahribata yol açmıştır. Geleneksel evlerin bulunduğu kırsal bölgelerde deprem ciddi hasarlara yol açmış ve bazı köyler haritadan silinmiştir. Episantr alana uzak oluşu nedeniyle 1904 depreminden en az etkilenen bölgelerinden birisi de Manastır vilayetiydi. ${ }^{26}$

\section{1905 Depremi}

22 Mart 1321 (4 Nisan 1905) tarihinde Görice sancağında deprem meydana gelmiştir. Depremden en çok İstarova kazası etkilenmiştir. Köhne bir durumda olan hükümet konağının çatısı yıkılmış ve konak kullanılamayacak hale gelmiştir. Onarımına değin çadır talep edilmiştir. Bu sırada Manastır'da bulunan İstarovalı Hüsrev Bey, kazada bulunan hanesinin geçici olarak hükümet konağı kullanımına elverişli olduğunu valiliğe bildirmiştir. ${ }^{27}$ Bunun üzerine Hüsrev Bey'in 14 odalı hanesi 16 Nisan'dan itibaren 300 kuruş kira bedeli karşılığında hükümet konağı olarak kullanılmak üzere kiralanmıştır. ${ }^{28}$

\section{1911 Depremi}

5 Şubat 1326 (18 Şubat 1911) tarihinde gece Manastır vilayetinde saat 21.35'te şiddeti $\mathrm{M}=6.7$ olarak ölçülen (Osmanlı belgelerinde deprem "şiddetli ve sürekli" tasvir edilmektedir) deprem meydana geldi. Unesco'nun Balkan bölgesinin sismisitesi ve meydana gelen depremlerle ilgili hazırlatmış olduğu deprem kataloğunda 18 Şubat'ta meydana gelen depremin saati 21.35

\footnotetext{
${ }^{24}$ BOA, MF. MKT, 241/38, 19 Teşrin-i Sani 1310 (1 Aralık 1894).

${ }_{25}$ BOA, DH. MKT, 838/15, 23 Mart 1320 (5 Nisan 1904).

${ }^{26}$ Nicholas N. Ambraseys, "The Kresna Earthquake of 1904 in Bulgaria”, Annali Di Geofisica, Vol. 44, N. 1, February 2001, s. 102.

${ }^{27}$ BOA, TFR. I.MN, 60-1/5909, 23 Mart 1321 (5 Nisan 1905).

${ }^{28}$ BOA, TFR. I.MN, 83/8234, 1 Kanun-i sani 1321 (14 Ocak 1906).
} 


\section{ÖZER ÖZBOZDAĞLI}

$\mathrm{M}=6.7$ olarak verilmektedir. Katalogda depremin hemen ardından biri 21 . 38 'de $\mathrm{M}=5.7$ ve diğeri $22: 59$ 'da $\mathrm{M}=5.2$ şiddetinde deprem meydana geldiği belirtilmektedir. Osmanlı belgelerinde ise depremin alaturka saatle 5.20'de meydana geldiği belirtilmektedir. Bu saat alafranga saate çevrildiği zaman ortalama saat 11.00'a (23.00) tekâmül etmektedir. ${ }^{29}$ Osmanlı belgelerinden biri şiddetli deprem ve arkasından meydana gelen şiddetli arţ̧ı şoklardan bahsetmektedir.

Manastır vilayetinde 18 Şubat 1911 tarihinde gece saat 11.00'da (alaturka saatle 05.20'de) deprem meydana gelmiştir. Depremde bazı hanelerin duvar ve bacaları yıkılmış, tevkifhanenin birinci ve ikinci koğuşlarının duvarları çatlamıştır. Manastır valiliği, vilayet merkezinde ölü ve yaralı olmadığını belirtmiştir. ${ }^{30}$ Deprem, vilayet merkezi ile merkez sancağa bağlı Ohri kazasında ve Görice sancağında etkili oldu. 1911 depremi özellikle Ohri-Görice hattındaki bölgeyi vurdu. Görice sancağına bağlı İstarova kazasında ve köylerinde ciddi yıkıma neden oldu. Ciddi hasar alanı güneye doğru Görice, duvarların ve bacaların yıkıldığg Bihlişte'den (nahiye) Manastır'a kadar uzanmaktadır.

Görice mutasarrıflı̆̆ının deprem ile ilgili ilk gönderdiği bilgilerde; depremin en etkili ve ciddi hasara neden olduğu İstarova (Boğradiç) kazasında halkın geceyi sokaklarda geçirdiği, haneler ve hükümet konağ1 ciddi hasar gördüğü için 300 çadıra ihtiyaç duyulduğu belirtilmekteydi. Bununla birlikte enkaz altında kalan üç kadının birisinin ölü, diğer ikisinin ise yaralı olarak çıkarıldığı bildirilmiştir. ${ }^{31}$ Görice Metropolitliği deprem ile ilgili Rum Patrikhanesine gönderdiği yazıda; deprem nedeniyle birçok bina ve meskenin yıkıldığını hasarın 50 bin lira civarında olduğunu ve bölge halkının yardıma muhtaç durumda olduğunu belirtmiştir. ${ }^{32}$

İstarova'da depremzedelere ekmek, odun ve kömür tedariki için ilk etapta 30.000 kuruş gönderilmiştir. Çadır tedariki için Manastır valiliği askeri

${ }^{29}$ Catalogue Of Earthquakes, Ed. N.V. Shebalin - V. Karnik, (Unesco Project), Skopje 1974, s. 37

${ }^{30}$ BOA, DH. MTV, 16-1/14, 6 Şubat 1326 (19 Şubat 1911); "Manastır'da Hareket-i Arz", Sabah, Nr: 7692, 20 Safer 1329 (Hicri), 7 Şubat 1326 (Rumi), 20 Şubat 1911 (Miladi), s. 2.

${ }^{31}$ BOA, DH. MTV, 16-1/14, 6 Şubat 1326 (19 Şubat 1911); Manastır'da Hareket-i Arz", Sabah, Nr: 7692, 7 Şubat 1326 (Rumi), 20 Şubat 1911 (Miladi), s. 2; Sabah, Nr: 7693, 21 Safer 1329 (Hicri), 8 Şubat 1326 (Rumi), 21 Şubat 1911 (Miladi), s. 1.

${ }^{32}$ Sabah, Nr: 7696, 24 Safer 1329 (Hicri), 11 Şubat 1326 (Rumi), 24 Şubat 1911 (Miladi), s. 2. 


\section{GÖRİCE SANCAĞINDA DEPREMLER (1893-1912)}

makamlara başvurmuştur. ${ }^{33}$ Kötü hava koşulları depremzedelerin hayat şartlarını bir kat daha zorlaştırmaktaydı. Fakir aileler ve memurlar yağmur sebebiyle dolayı eşyalarının zarar örmesinden dolayı bir kat daha zorluk çekmekteydiler. Görice mutasarrıflığı bu sebeple memurlara maaşlarının yarıs1 nispetinde yardım yapılamasını talep etmiştir. ${ }^{34}$ İstarova'daki depremzedeler için Görice'de bir iane komisyonu kurularak ilk etapta 3000 kuruş iane toplanmıştır. ${ }^{35}$ İstarova kazasında depremden meskenleri yıkılan ve harap olan ihtiyaç sahibi aileler için toplanan 37.907 kuruşun yeniden inşa edilecek olan rüştiye mektebinin inşasına harcanmasına karar verilmiştir. ${ }^{36}$

İstarova kaymakamlığı depremin hemen ardından köylerde yaptırdığ 1 hasar tespit çalışmalarında Zagorcan, Tuşeşine, Cerlenve, Bratoşa, Peşince, Zir-i Vaska, Bredeve, Mahlişene, Sudolinşete,Zireneba, Malina, Bileşişte, Langa köylerindeki hanelerin tamamen ya da kısmen hasar gördügünü tespit etmiştir. ${ }^{37}$ Hodonişte köyünde mevcut 57 hanenin 20'si tamamen, geri kalanı da kısmen çökmüş ve halk geceyi samanlıklarda geçirmiştir. Hodonişte köyünde ikisi kadın ikisi çocuk dört kişi hafif şekilde yaralanmıştır. Homcan köyünde ise 28 hane y1kılmıştır. ${ }^{38}$

Depremin en büyük artçı şoku 20 Şubat'ta meydana geldi. İstarova'da 20 Şubat'ta meydana gelen artçı sarsıntılarda bazı hanelerde hasar meydana gelirken, hasarlı olan bazı haneler de kullanılamaz hale gelmiştir. ${ }^{39}$ İstarova'da 5 Mart'ta şiddetli bir arţ̧ı şok yaşanmış ve kaza merkezinde bulunan bir otelin duvarları çökmüştür. ${ }^{40}$

1911 Şubat'inda İstarova kazasında meydana gelen şiddetli deprem 1912 yılında da aynı ayda meydana gelmiştir. Depremde İstarova'nın Dubiçine Balkanı'ndan kopan dağ parçası altında kalan Koca Hasan'ın zevcesi Cemile ile Patkojan köyü çobanı ve Maline köyünde 15 yaşlarında Kamil'in vefat ettiği tespit edilmiştir. Dubiçine köyünde birçok hanenin depremde mahvolduğu, Ustan köyünde de birkaç hanenin yıkıldığı

\footnotetext{
${ }^{33}$ BOA, DH. MTV, 16-1/14, 6 Şubat 1326 (19 Şubat 1911); Manastır'da Hareket-i Arz", Sabah, Nr: 7692, 7 Șubat 1326 (Rumi), 20 Şubat 1911 (Miladi), s. 2; Sabah, Nr: 7693, 8 Şubat 1326 (Rumi), 21 Şubat 1911 (Miladi), s. 1.

${ }^{34}$ BOA, BEO, 3882/291146, 12 Mart 1327 (25 Mart 1911).

${ }^{35}$ BOA, DH. MTV, 16-1/14, 10 Şubat 1326 (23 Şubat 1911).

${ }^{36}$ BOA, DH. MTV, 16-1/19, 24 Temmuz 1328 (6 Ağustos 1912).

${ }^{37}$ BOA, DH. MTV, 16-1/14, 8 Şubat 1326 (21 Şubat 1911).

${ }^{38}$ BOA, DH. MTV, 16-1/14, 10 Şubat 1326 (23 Şubat 1911).

${ }^{39}$ BOA, DH. MTV, 16-1/14, 8 Şubat 1326 (21 Şubat 1911).

${ }^{40}$ BOA, DH. MTV, 16-1/14, 22 Şubat 1326 (5 Mart 1911).
} 


\section{ÖZER ÖZBOZDAĞLI}

bildirilmiştir. İstarova kaymakamlığı açıkta kalan halk için 15 adet çadır talep etmiştir. ${ }^{41}$

Merkez sancağa bağlı Ohri kazasında aynı saatte meydana gelen ve 15-20 saniye sürdügü belirtilen deprem ciddi hasara yol açmıştır. Birçok evin yıkılmasının yanı sıra camilerin minareleri düşmüş ve Ohri Gölü'nün seviyesi 50 santimetreye yükselmiştir. ${ }^{42}$ Ohri kaymakamlığının gönderdiği ilk bilgilerde; birçok hanenin duvarı, üç minare ile bir çamaşırlı̆̆ın yıkıldığı belirtilmekteydi. İlk gelen bilgilerde ölü ve yaralının olmadığı bildirilmiştir. Hasar tespit çalışmalarına hemen başlanılması için Ohri kaymakamlığına talimat verilmiştir. ${ }^{43}$ Ohri kaymakamlığı depremin hemen ardından yaptığı ilk hasar tespit çalışmalarında; kaza merkezinde bazı yapıların tamamen yıkıldığını, sukuf mahallesinde iki minarenin yıkılarak camileri kullanılamaz hale getirdiğini, Hacı Kasım camisinin her tarafında çatlaklar oluştuğu için içerisine girilemediğini, Struga nahiyesinde ciddi hasar meydana geldiğini tespit etmiştir. ${ }^{44}$ Ohri' de 22-23 Şubat'ta meydana gelen artçı şoklarda hasarlı bazı yapılar tamamen çökmüş, Bulgar mektebinin sıvaları dökülmüş ve bazı kiliselerde çatlaklar oluşmuştur. ${ }^{45}$

Ohri kazasında camiler depremde ciddi hasar görmüştü. Halk camilerin 1912'de hala yaptırılmadığı gerekçesiyle Ohri kaymakamlığına başvurmuştur. Ohri kazası dâhilinde yıkılan veya zarar gören 9 caminin hasar keşif bedelleri toplam 131.652 kuruş olarak tespit edilmiştir. ${ }^{46}$ Hasar tespit çalışmalarından sonra Ohri kazası ve Struga nahiyesindeki 7 caminin tamiratları için gerekli olan 66.330 kuruşluk tutar 9 Mayıs 1912 tarihinde Manastır Evkaf Müdüriyeti'ne gönderilmiştir. ${ }^{47}$

${ }^{41}$ BOA, DH. MTV, 16-1/16, 4 Şubat 1327 (17 Şubat 1912).

${ }^{42}$ Shyqyri Aliaj - Siasi Koçiu - Betim Muço - Eduard Sulstarova, Seismicity, Seismotectonics And Seismic Hazard Assessment In Albania, Academy of Sciences of Albania, Tiran 2010, s. 8; Arşiv belgelerinde depremin alaturka saatle 5.20'de meydana geldiği belirtilmektedir. O gün akşam ezanının okunduğu 5.40'a beş saat yirmi dakika eklediğimizde depremin 5 Şubat (18 Şubat) gecesi saat 11.00 'da meydana geldiğini söyleyebiliriz.

${ }^{43}$ BOA, DH. MTV, 16-1/14, 6 Şubat 1326 (19 Şubat 1911); Manastır'da Hareket-i Arz”, Sabah, Nr: 7692, 20 Safer 1329 (Hicri), 7 Şubat 1326 (Rumi), 20 Şubat 1911 (Miladi), s. 2.

${ }^{44}$ BOA, DH. MTV, 16-1/14, 6 Şubat 1326 (19 Şubat 1911); Tanin, Nr: 888, 22 Safer 1329 (Hicri), 9 Şubat 1326 (Rumi), 22 Şubat 1911 (Miladi), s.4; Sabah, Nr: 7694, 22 Safer 1329 (Hicri), 9 Şubat 1326 (Rumi), 22 Şubat 1911 (Miladi), s. 3.

${ }^{45}$ BOA, DH. MTV, 16-1/14, 10 Şubat 1326 (23 Şubat 1911).

${ }^{46}$ BOA, DH. MUI, 157/44, 21 Nisan 1328 (4 May1s 1912); BOA, DH. MUI, 157/44, 23 Nisan 1328 (6 May1s 1912).

${ }^{47}$ BOA, DH. MUI, 157/44, 26 Nisan 1328 (9 May1s 1912); BOA, DH. MUI, 157/46, 29 Nisan 1328 (12 Mayis 1912). 
19 Şubat'ta meydana gelen depremde Resne kazasında ise sekiz baca, iki duvarla iki tavan çökmüştür. Pirlepe, Kesriye, Kolonya kazalarında da hissedilen depremde herhangi bir hasar olmadığı belirtilmiştir. Debre kazasında da 19 Şubat gecesi biri "şiddetli ve sürekli" biri hafif iki deprem meydana gelmiştir. ${ }^{48}$ Florina, Kırçova ve İlbasan'da 19 ve 20 Şubat'ta muhtelif zamanlar da deprem meydana geldiği ve herhangi bir hasar olmadığı belirtilmiştir. ${ }^{49}$

18 Şubat 1911 depreminin arţ̧ı şokları 1911 ve 1912 yılları boyunca devam etmiştir. Manastır Valiliği devam eden artçı sarsıntıları düzenli bir şekilde Dâhiliye Nezareti'ne bildirmiştir.

Ohri gölü ve havzasında sık sık meydana gelen depremler üzerine Manastır valiliği Dâhiliye Nezareti’nden Ohri gölünün eski ve sönmüş bir volkan arazi olduğunun rivayet edildiğini belirterek ileride meydana gelebilecek şiddetli bir depreme karşı önlem alabilmek için bölgede tetkikat ve fenni incelemeler yapmak üzere bir uzamanın gönderilmesini talep etmiştir. ${ }^{50}$ Osmanlı hükümeti yapılan incelemeden sonra; Ohri havalisinde bir sönmüş volkan bulunmasının ihtimal dışı olduğunu, olsa bile ileride meydana gelebilecek depremin şimdiden tahmin edilmesinin mümkün olmadığını, bu yüzden bir uzmanın ancak bölgenin haritasını çıkarabileceğini belirtmiştir. ${ }^{51}$

İstarova ve Ohri'de yapılan hasar tespit çalışmaları sonunda; İstarova kaza merkezi ile köylerinde toplam hasar miktarı tahmini 660.300 kuruş, Ohri kaza merkezi ile köylerinde toplam hasar miktarı tahmini 12.000 lira olarak hesaplanmıştır. Ohri'de tespit edilen rakama resmi binalar ve camiler dâhil edilmemiştir. Manastır valiliği her iki kaza merkezinde ihtiyaç sahipleri için 7000 liraya ihtiyaç duyulduğunu hükümete bildirmiştir. Osmanlı hükümeti 7000 bin liradan mümkün olan rakamın hükümetçe gönderilmesine geri kalanının ise ianeten tedarikine karar vermiştir. ${ }^{52}$

\footnotetext{
${ }^{48}$ BOA, DH. MTV, 16-1/14, 6 Şubat 1326 (19 Şubat 1911); BOA, DH. MTV, 16-1/14, 8 Şubat 1326 (21 Şubat 1911).

${ }^{49}$ BOA, DH. MTV, 16-1/14, 7 Şubat 1326 (20 Şubat 1911); BOA, DH. MTV, 16-1/14, 10 Şubat 1326 (23 Şubat 1911); Sabah, Nr: 7696, 24 Safer 1329 (Hicri), 11 Şubat 1326 (Rumi), 24 Şubat 1911 (Miladi), s. 2.

${ }^{50}$ BOA, DH. MTV, 16-1/16, 11 Mart 1328 (24 Mart 1912).

${ }^{51}$ BOA, DH. MTV, 16-1/16, 17 Nisan 1328 (30 Nisan 1912).

${ }^{52}$ BOA, $M V, 151 / 14,29$ Mart 1327 (11 Nisan 1911).
} 


\section{ÖZER ÖZBOZDAĞLI}

Manastır vilayetinde meydana gelen depremden sonra açıkta kalan halk için 580 çadır askeri makamlar tarafından afet bölgesine gönderilmiştir. ${ }^{53}$ Osmanlı hükümeti çadırlara ihtiyaç kalmayınca askeriyeye iade edilmesine karar vermiştir. Afet yönetiminin en önemli konu başlıklarından biri depremzedelerin barınma problemi olduğu için bir afet meydana geldiğinde depolarda çadırların hazır bulundurulması ve harap olmaması için bu karar alınmıştır. $^{54}$

Osmanlı hükümeti 1911 yılı bütçesinden Ohri ve İstarova'ya 300 Lira gönderme kararı almıştır. Bu paranın 200 lirasının İstarova, 100 lirasının da Ohri depremzedelerine kullanılması kararlaştırılmıştır. ${ }^{55}$ Padişah depremzedeler için 20 bin kuruş bağışlamıştır. ${ }^{56}$ Osmanlı hükümeti depremden dolayı tamamen yık1lan emlak ve bina sahiplerinin, emlak ve temettü vergisinden muaf tutulmalarına karar vermiştir. ${ }^{57}$

1911 Manastır depremi, Makedonya meselesinin en kritik yılında meydana gelmiş ve Ohri-Görice hattında ciddi hasara neden olmuştu. Osmanlı hükümeti Makedonya meselesinin hassasiyeti ve komitaciların istismar alanlarını kapatmak için afet yönetimi konusuna önem vermiş, özellikle fakir halkın ihtiyaçlarının karşılanması noktasında hassas davranmıştır. Ohri ve Görice bölgesinde deprem sonrası yapılamayan ve eksik kalan yatırımlar 1912'de Hacı Adil Bey başkanlığında Makedonya 1slahatı için kurulan Rumeli Islahat Komisyonu tarafindan yapılamaya çalışılacaktır.

\section{Sonuç}

Deprem insana zarar veren ve yaşamını derinden etkileyen, sosyal ve ekonomik kayıplara neden olan bir doğal afettir. Bu açıdan depremler sonuçları itibarıyla tarihsel olguların da ortaya çıkmasına neden olmaktadır. Depremin insan üzerinde yarattığı etki ve travmalar, can kayıpları, göç,

\footnotetext{
${ }^{53} 580$ adet çadırın değeri 200.403 kuruş olarak hesaplanmıştır. Askerî makamlar bu bedelin ödenmesi için hükümete başvurmuşlardır. BOA, BEO, 3865/289825, 20 Şubat 1326 (5 Mart 1911).

${ }^{54}$ BOA, BEO, 3889/291601, 18 Nisan 1327 (1 Mayis 1911).

55 BOA, MV, 153/1, 22 Mayis 1327 (4 Haziran 1911); BOA, BEO. 3091/292552, 23 May1s 1327 (6 Haziran 1911).

${ }^{56}$ BOA, $B E O, 2861 / 289526,10$ Şubat 1326 (23 Şubat 1911).

${ }^{57}$ BOA, BEO, 4098/306586, 13 Eylül 1328 (26 Eylül 1912).
} 


\section{GÖRİCE SANCAĞINDA DEPREMLER (1893-1912)}

coğrafyanın yeniden şekillenmesi, yerleşim yerlerinin yeniden inşası gibi konular depremin sonuçları olarak incelenmesi gereken tarihsel olgulardır. Bununla birlikte tarihsel örneklerin incelenmesi gelecekte meydana gelebilecek depremler için öngörüde bulunulabilmesi için de önem taşımaktadır. Arşiv belgelerinde depremin teknik analizlerinin olmaması, insanlar üzerindeki etki ve sonuçlarının ayrıntılarının sınırlı olması, yapıların durumu ve mimari özellikleri, şehirlerin yeniden inşası gibi ayrıntıların olmaması bir deprem çalışmasının en önemli zorluklarını oluşturmaktadır.

Osmanlı Makedonyası Balkan Yarımadası'nın en tehlikeli ve sismik olarak en aktif bölgelerinden biridir. Makedonya tarihsel süreçte birçok depremden etkilendi. Makedonya coğrafyasında Vardar-Üsküp ve StrugaOhri-Görice bölgeleri depremlerin en sik yaşandığı bölgelerdir. Manastır vilayetinde 1893-1912 yılları arasında Ohri-Görice bölgesinde çok sık depremler meydana gelmiştir. 1893-1912 döneminde meydana gelen depremler zaten ekonomik-siyasi sorunlarla uğraşan Osmanlı Devleti'nin beklenmedik harcamalar yapmasına neden olmuştur. Arşiv belgeleri, deprem için bütçede tanımlanmış harcama kalemleri olmadığı için özelikle kamu binalarının onarımı ya da yeniden inşası, çadırların bedelinin askeriyeye ödenmesi gibi konularda uzayıp giden yazışmalarla doludur.

Makedonya meselesinin uluslararası bir sorun olarak Osmanlı gündemine oturduğu hassas bir dönemde meydana gelen bu depremlerde Osmanlı Devleti'nin sergileyeceği afet yönetimi konusu oldukça önemli bir hale gelmekteydi. Kırsal alanlarda ciddi hasara yol açan bu depremlerde komitacıların istismar alanlarını da kapatmak için Osmanlı Devleti afet yönetimi konusunda hızlı davranmıştır. Özellikle fakir halkın barınma ve beslenme ihtiyaçlarının karşılanması, hanelerinin yeniden inşa edilmesi konusunda başarılı bir afet yönetimi sergilenmiştir. Merkezi hükümet, Manastır Valiliği'ni afet yönetimi konusunda yaşanan aksaklıklar konusunda sürekli uyarmıştır. Özellikle barınma ihtiyaçlarının karşılanması noktasında çadır önemli bir yere sahipti. Bu konuda askeri makamlara doğrudan Padişahın talimatı iletilmiştir. Devletin yetersiz kaldığı noktada iane (yardım) toplanmış ve halkın ihtiyaçları karşılanmaya çalışılmıştır. Ohri-Görice bölgesinde, depremin izleri ve verdiği zararın ortadan kaldırılması için eksik kalan yatırımlar 1912 yılında Makedonya ıslahatı için kurulan Rumeli Islahat Komisyonu tarafından yapılmaya çalışılacaktır.

1911-1912 y1llarında meydana gelen depremlerden sonra Manastır Valiliği coğrafyada yaşanan depremlerin sebebinin araştırılması için 


\section{ÖZER ÖZBOZDAĞLI}

İstanbul'dan uzman istemiştir. Ancak devletin deprem konusunda yetişmiş teknik elamanı olmadığ için teknik analizler yapılamamıştır.

\section{KAYNAKÇA}

\section{Arşiv Belgeleri}

\section{Başkanlık Osmanlı Arşivi (BOA)}

Babıâli Evrak Odası (BEO) 276/20686; 122/31639; 283/21217; 2307/173008; 3882/291146; 3865/289825; 3889/291601; 3091/292552; 2861/289526; 4098/306586.

Dâhiliye Nezareti Mektubi Kalemi (DH. MKT) 102/33; 132/32; 131/3; 79/15; 838/15; 838/47.

Dâhiliye Nezareti Mütenevvia (DH. MTV) 16-1/14; 16-1/19; 16-1/16.

Dâhiliye Nezareti Muhaberat-ı Umumiye İdaresi (DH. MUİ) 157/44; 157/46. Irade Dâhiliye (I. DH) 1307/16; 1307/42.

Maarif Nezareti Mektubi Kalemi (MF. MKT) 241/38.

Meclis-i Vükela Mazbataları (MV) 151/14; 153/1.

Teftişat-ı Rumeli Evrakı Manastır Evrakı (TFR. I.MN) 60-1/5909; 83/8234.

Ylldız Hususi Maruzat (Y.A. HUS) 271/42;449/43; 279/99.

Yıldız Mütenevvi Maruzat (Y. MTV) 160/145; 167/249; 175/198.

Yıldız Dâhiliye Nezareti Maruzatı (Y.PRK. DH) 10/36.

\section{Süreli Yayınlar}

Sabah 


\section{GÖRICE SANCAĞINDA DEPREMLER (1893-1912)}

Tanin

\section{Kitaplar ve Makaleler}

ALİAJ, Shyqyri - KOÇİU, Siasi - MUÇO, Betim - SULSTAROVA, Eduard, Seismicity, Seismotectonics and Seismic Hazard Assessment in Albania, Academy of Sciences of Albania, Tiran 2010, s. 1-99.

AMBRASEYS, Nicholas, Earthquakes in the Mediterranean and Middle East, Cambridge University Press, UK 2009.

, "The Kresna Earthquake of 1904 in Bulgaria", Annali Di Geofisica, Vol. 44, N. 1, February 2001, s. 95-102.

Catalogue of Earthquakes, Ed. N. V. Shebalin - V. Karnik, (Unesco Project), Skopje 1974.

MILUTINOVIC, Zoran - ANASTASOVSKA, Dragana, "Seismic Hazard And Review of Seismic Activity of the Ohrid Epicentral Area in the Period June- July 2017”, Geographical Reviews, 2017, s. 41-52.

REICHERTER, Klaus R. - FERNANDEZ-STEEGER, Tomas Manuel, "Active Tectonics in the Ohrid Basin (Macedonia/Albania)", EGU General Assembly, April 2009, s. 1-2.

SULOLLARİ, Mentor, "Natural Hazards in the Albanian Area of Lake Ohrid", Annals of Valahia University of Targoviste. Geographical Series, 2016, s. 87-93.

ŞAHIN, Cemalettin - SiPAHIOĞLU, Şengün, Doğal Afetler ve Türkiye, Gündüz Eğitim ve Yayıncılık, Ankara 2007.

ÜNLÜ, Mucize, Manastır Vilayeti'nin İdari ve Sosyal Yapısl (1873-1912), Ondokuz Mayıs Üniversitesi Sosyal Bilimler Enstitüsü, Yayınlanmamış Yüksek Lisans Tezi, Danışman: Yrd. Doç. Dr. M. Emin Yolalıcı, Samsun 1996. 
ÖZER ÖZBOZDAĞLI

\section{İnternet Kaynakları}

"Seismicity of Republic of Macedonia: Tectonics and observed seismicity, http://seismobsko.pmf.ukim.edu.mk/index.php/mk/seismicity/seismicity-ofrepublic-of acedonia/observed-seismicity/54-tectonics-and-observedseismicity, (28.7.2019). 


\section{GÖRİCE SANCAĞINDA DEPREMLER (1893-1912)}

EK 1. Manastır Vilayetinde Meydana Gelen Diğer Depremler ${ }^{58}$

\begin{tabular}{|c|c|c|c|}
\hline $\begin{array}{l}\text { Depremin meydana } \\
\text { geldiği yer }\end{array}$ & Oluş Zamanı & Şiddeti & Hasar \\
\hline Resne & $\begin{array}{l}2 \text { Haziran } \\
1893\end{array}$ & Şiddetli & --------------- \\
\hline Görice & 4 Şubat 1894 & Artç1 şok & \\
\hline $\begin{array}{c}\text { Florina } \\
\text { (Ohrid ve Prespa } \\
\text { gölleri çevresinden } \\
\text { rapor edilmiştir. } \\
\text { Uzmanlar Episantr } \\
\text { alanının Florina } \\
\text { olabileceğini } \\
\text { belirtmektedir). }\end{array}$ & $\begin{array}{l}\text { 22-24 Ağustos } \\
1894\end{array}$ & - & $\begin{array}{c}\text { (Görice, Florina } \\
\text { ve Ohri } \\
\text { bölgelerinde } \\
\text { baz1 hasarlara } \\
\text { neden oldu) }\end{array}$ \\
\hline $\begin{array}{c}\text { Görice (Deprem } \\
\text { Ohri gölü çevresinde } \\
\text { hissedildi) }\end{array}$ & 11 Şubat 1896 & Şiddetli & ---------------- \\
\hline Görice & $\begin{array}{l}4 \text { Haziran } \\
1896\end{array}$ & Şiddetli & \\
\hline Manastır- Görice & 18 Ocak 1897 & $\begin{array}{c}\text { 17-20 Ocak } \\
1897 \text { aras1 } \\
\text { baz1 } \\
\text { sarsintılar }\end{array}$ & \\
\hline $\begin{array}{c}\text { Debre-i Bala ve } \\
\text { Debre-i Zir }\end{array}$ & 9 Mayıs 1897 & Şiddetli & --------------- \\
\hline Görice & $\begin{array}{c}\text { 15/16 Haziran } \\
1897 \text { Gecesi } \\
1: 45 \\
\end{array}$ & Şiddetli & $\begin{array}{l}\text { Bazı hane ve } \\
\text { bacalar } \\
\text { yıkılmıştır. }\end{array}$ \\
\hline Görice & 25 Eylül 1897 & $\begin{array}{c}1 \text { defa } \\
\text { şiddetli } \\
3 \text { defa hafif } \\
\end{array}$ & -------------- \\
\hline Debre & 2 Nisan 1898 & 1 defa hafif & --------------- \\
\hline İlbasan & $\begin{array}{c}4 \text { Haziran } \\
1903\end{array}$ & Şiddetli & $\begin{array}{c}\text { Peklin kazası ve } \\
\text { köylerinde bazı } \\
\text { yapılar } \\
\text { yıkılmıştır. }\end{array}$ \\
\hline
\end{tabular}

${ }^{58}$ BOA, Y.PRK. DH, 10/36, 28 Nisan 1313 (10 May1s 1897); BOA, Y. MTV, 160/145, 4 Haziran 1313 (16 Haziran 1897); BOA, Y. MTV, 167/249, 13 Eylül 1313 (26 Eylül 1897); BOA, $Y$. MTV, 175/198, 22 Mart 1314 (3 Nisan 1898); Ambraseys, a.g.e., s. 771; BOA, Y.A.HUS, 449/43, 22 Mayis 1319 (4 Haziran 1319). 
ÖZER ÖZBOZDAĞLI

\begin{tabular}{|c|c|c|c|}
\hline Kırçova & 1907 & Şiddetli & $\begin{array}{c}\text { Kırçova } \\
\text { kazasına tabi } \\
\text { İsterliçe } \\
\text { köyünde } \\
\text { meydana gelen } \\
\text { deprem } \\
\text { neticesinde } 16 \\
\text { hane } \\
\text { kullanılamaz } \\
\text { hale gelmiştir. } \\
\text { Haneleri } \\
\text { kullanılamaz } \\
\text { hale gelen } 30 \\
\text { kadar nüfus } \\
\text { başka hanelere } \\
\text { yerlestirilmistir. }\end{array}$ \\
\hline
\end{tabular}

